\title{
Pengembangan Laboratorium Virtual Berbasis Pendidikan Karakter untuk Siswa Sekolah Dasar
}

\author{
Aris Naeni Dwiyanti, Mawan Akhir Riwanto, Wahyu Nuning Budiarti \\ Universitas Nahdlatul Ulama Al Ghazali Cilacap \\ aris@unugha.ac.id.com
}

\section{Article History}

accepted 24/09/2019

approved 01/10/2019

published 01/12/2019

\begin{abstract}
This study aims to 1) Develop prototype technology in the form of character education based virtual laboratories 2) Know the quality of prototype technology in the form of character education based virtual laboratories. This type of research is research and development research using the Borg \& Gall research model which consists of 10 stages. Subjects, populations and samples in this study include teachers, Elementary School Students, Media Specialists, Material Experts, Linguists and Psychologists. The results of this study are 1) The prototype of technology in the form of a virtual laboratory based on character education for class IV 2013 curriculum consists of 1 theme, in 1 the theme consists of 8 experiments 2) The quality of the virtual laboratory according to the assessment of media experts, material experts, linguists, experts psychology, teachers, and students are in the good category.
\end{abstract}

Keywords: Research and Development Research, Character Education, Virtual Laboratory, Natural Sciences

\begin{abstract}
Abstrak
Penelitian ini bertujuan untuk 1)Mengembangkan teknologi purwarupa berupa laboratorium virtual berbasis pendidikan karakter 2) Mengetahui kualitas teknologi purwarupa berupa laboratorium virtual berbasis pendidikan karakter. Jenis penelitaian ini adalah penelitian riset dan pengembangan dengan menggunakan model penelitian Borg \& Gall yang terdiri dari 10 tahapan. Subjek, populasi dan sampel dalam penelitian ini antara lain guru, Siswa Sekolah Dasar, Ahli Media, Ahli Materi,Ahli Bahasa Dan Ahli Psikologi. Hasil dari penelitian ini adalah 1) Purwarupa teknologi berupa laboratorium virtual berbasis pendidikan karakter untuk kelas IV kurikulum 2013 terdiri dari 1 tema, dalam 1 tema tersebut terdiri dari 8 percobaan 2) Kualitas laboratorium virtual menurut penilaian ahli media, ahli materi,ahli bahasa, ahli psikologi, guru, dan siswa masuk kategori baik.
\end{abstract}

Kata kunci: Penelitian Riset dan Pengembangan, Pendidikan Karakter, Laboratorium Virtual, Ilmu Pengetahuan Alam

Social, Humanities, and Education Studies (SHEs): Conference Series https://jurnal.uns.ac.id/shes

p-ISSN 2620-9284

e-ISSN 2620-9292 


\section{PENDAHULUAN}

Krisis moral pelajar saat ini menjadi sorotan yang serius. Mulai dari maraknya tawuran pelajar hingga yang sering dilupakan yaitu kepedulian pelajar terhadap lingkungan sekitar. Bidang pendidikan menjadi salah satu pilar utama dan menjadi ujung tombak yang diharapkan dapat mengatasi permasalahan krisis moral tersebut. Salah satu kebijakan nasional dari pemerintah yaitu penerapan pendidikan karakter di sekolah-sekolah. Kebijakan ini dimulai dari penyisipan penilaian sikap siswa hingga penyisipan nilai-nilai moral di semua mata pelajaran. penanaman sikap religius dan sikap sosial, dapat dicapai dengan memanfaatkan pembelajaran tidak langsung hal ini dapat berupa kejujuran, kebiasaan, serta kearifan sekolah, dengan melakukan analisis komponen mata pelajaran, serta kebutuhan dan minat siswa. Pembentukan dan pengembangan kompetensi sikap dilakukan secara terus menerus sepanjang pembelajaran berlangsung, dan dapat digunakan sebagai bahan penentu kebijaksanaan guru dalam meningkatkan karakter siswa.

Kenyataan yang ada di lapangan saat ini adalah tuntutan bagi guru dalam turut serta aktif dalam pendidikan karakter. Pendidikan karakter menjadi sesuatu yang diabaikan dalam muatan pembelajaran ilmu eksakta, yaitu matematika dan IImu Pengetahuan Alam (IPA). Hal ini dikarenakan karakter ilmu eksakta lebih mengutamakan penguasaan konten, baik itu penguasaan konsep maupun pengetahuan dari pada pembentukan karakter siswa. Salah satu kendala kurangnya penumbuhan pendidikan karakter dalam mata pelajaran IPA adalah pelaksanaan praktikum yang menyita banyak waktu, disamping tuntutannya adalah siswa mampu memahami dan mengaplikasikan konsep yang sedang dipelajari sehingga pendidikan karakter kurang menjad perhatian. Karakter dari mata pelajaran IPA harusnya sangat mendukung pendidikan karakter.

Dalam mata pelajaran IPA banyak sekali konsep-konsep yang bisa dikemas menjadi suatu pendidikan karakter saat praktikum. Materi IPA pada tema Pahlawanku yang memuat materi tentang sifat sifat cahaya menjadi salah satu materi yang dapat disisipi pendidikan karakter. Pada bagian ini perlu dijelaskan uraian tentang spesifikasi khusus terkait dengan skema. materi sifat cahaya adalah materi pelajaran berpraktik. Kompetensi pengetahuan dalam materi ini adalah menerapkan sifat-sifat cahaya dan keterkaitannya aplikasi sifat-sifat cahaya pada zaman dulu maupun sekarang, sedangkan kompetensi keterampilannya adalah membuat laporan tentang pengamatan dan/atau percobaan materi sifat-sifat cahaya dan pemanfaatan sifat tersebut dalam kehidupan zaman dahulu maupun zaman sekarang. Hal ini berhubungan dengan bumi Indonesia merupakan daerah tropis yang memiliki intensitas sinar matahari yang melimpah sehingga materi ini sesuai untuk memupuk karakter nasionalis (cinta tanah air), religius (toleransi), mandiri (kreatif), integritas (komitmen moral/ tanggung jawab) dalam diri siswa.

Berdasarkan permasalahan tersebut maka peneliti melakukan pengembangan teknologi purwarupa pembelajaran IPA berbentuk laboratorium virtual berbasis pendidikan karakter pada materi sifat-sifat cahaya. Dengan pertimbangan bahan dan alat praktikum yang tersedia di lapangan belum mencukupi kebutuhan praktikum di setiap sekolah.

\section{METODE}

Metode penelitian yang digunakan dalam penelitian ini adalah penelitian dan pengembangan atau research and development yang dikembangkan oleh Borg \& Gall. Metode penelitian ini digunakan untuk mengembangkan teknologi purwarupa pembelajaran IPA berupa laboratorium virtual berbasis pendidikan karakter. Selain itu juga metode ini digunakan untuk menguji tingkat kualitas dari hasil teknologi yang dikembangkan. Langkah- langkah dalam penelitian pengembangan menurut Borg \& Gall ada 10 tahapan yang terdiri dari: Penelitian dan pengumpulan informasi, 
perencanaan. Langkah keempat uji coba lapangan awal dilanjutkan dengan Revisi terhadap produk awal, uji coba utama dilanjutkan dengan revisi produk operasional, dilanjutkan dengan uji coba operasional, hasil dari uji coba tersebut kemudian diperbaiki disebut dengan revisi akhir setelah melakukan perbaikan maka produk siap untuk di sebarkan dan implementasikan. Penelitian ini dilakukan selama 9 bulan dari bulan januari-september 2019 .

\section{HASIL DAN PEMBAHASAN}

Berdasarkan model penelitian yang digunakan yaitu model penelitian pengembangan borg and gorl, hasil dari pengembangan laboratorium virtual diuraikan sesuai dengan tahapan-tahapan pengembangan penelitian yang digunakan adalah sebagai berikut:

1) Tahapan pertama adalah Penelitian dan pengumpulan informasi. Pada tahap ini dilakukan sudi literature terkait dengan rencana pengembangan produk. pengumpulan informasi berupa materi yang diperoleh dari berbagai macam sumber seperti buku cetak erlangga, Buku guru dan buku siswa membuat serta mengumpulkan gambar dari berbagai sumber, seperti gambar lilin, gambar kertas karton, gambar cermin datar, gambar cermin cembung, gambar cermin cekung sebagai bahan pengembangan laboratorium virtual. Selanjutnya dilakukan analisis percobaan berbasis pendidikan karakter yang dapat dikembangkan sebagai laboratorium virtual sesuai dengan kompetensi dasar pelajaran IPA kelas IV kurikulum 2013.

2) Tahap kedua adalah Perencanaan, kami merencanakan untuk mengembangkan 3 pokok bahasan utama yang meliputi halaman depan, halaman daftar menu percobaan, dan halaman pendidikan karakter. Berikut merupakan tampilan halaman depan laboratorium virtual ;

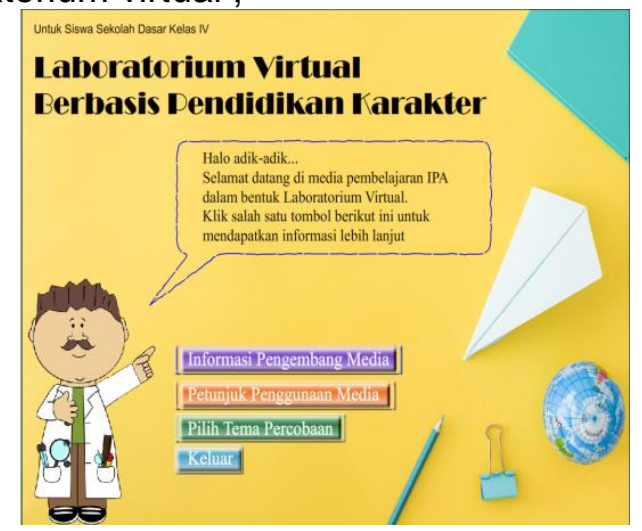

Gambar 1. Halaman depan laboratorium virtual

3) Setelah merencanakan produk tahapan selanjutnya adalah Pengembangan bentuk produk pendahuluan, hal ini dimulai dengan menyusun 4 tahapan pengembanagan diantaranya yaitu : a) pengumpulan informasi materi percobaan siswa yang dapat disesuaikan dengan pendidikan karakter, b) Penulisan Draft berisi 8 percobaan dari tema pahlawanku muatan pembelajaran IImu Pengetahuan Alam kelas IV kurikulum 2013, c. Penyusunan laboratorium virtual berdasarkan draft percobaan yang disusun, d. penyuntingan laboratorium virtual yang dilakukan oleh ahli materi, ahli media, ahli bahasa, serta ahli psikologi, berikut merupakan tampilan yang disunting oleh ahli media tentang tampilan menu yang dinilai masih terlalu kecil sehingga pengguna agak kesulitan dalam menemukan menu untuk kembali ke halaman depan. Masukan dari ahli psikologi tentang warna yang digunakan disarankan agar memakai warna yang dapat menarik perhatian siswa, berikut merupakan gambaran daftar percobaan laboratorium virtual dan halaman pendidikan karakter dari laboratorium virtual 


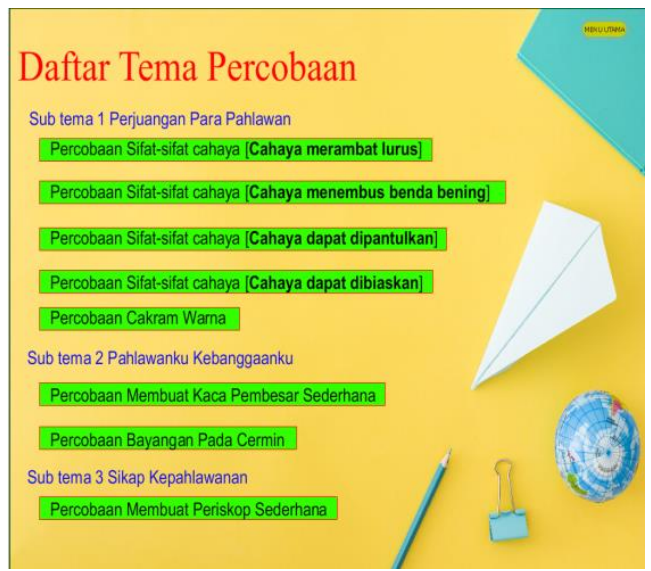

Gambar 2. Daftar percobaan laboratotium virtual

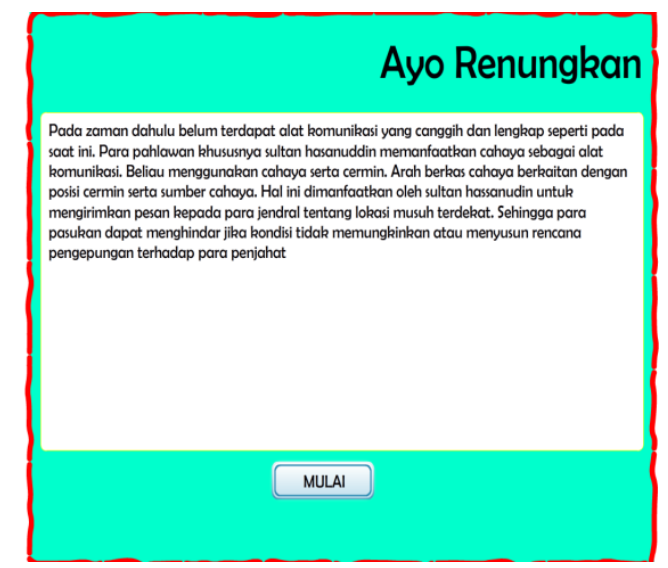

Gambar 3. Halaman pendidikan karakter

4) Setelah dilakukan pengembangan produk awal tahapan selanjutnya adalah Uji coba lapangan awal. Kegiatan ini digunakan untuk menguji produk awal yang telah dikembangkan. Tahap uji coba lapangan awal ini dilakukan di SD Negeri 1 Tambaknegara Kecamatan Rawalo Kabupaten Banyumas dengan melibatkan 1 guru dan 3 siswa kelas IV.

5) Hasil dari uji coba lapangan awal kemudian dilakukan revisi terhadap produk awal. Revisi dilakukan berdasarkan masukan saran dan kritik dari siswa dan guru SD Negeri 1 Tambaknegara tempat dilakukan uji coba lapangan awal.

6) Hasil dari revisi uji coba lapangan awal kemudian dilanjutkan dengan uji coba utama, subjek dari uji coba utama adalah 1 kelas dan 1 orang guru dari SD negeri 3 Rawalo. Dalam uji coba ini guru dan siswa mengisi angket terkait dengan teknologi purwarupa yang dikembangkan yaitu laboratorium virtual.

7) Setelah dilakukan uji coba utama kemudian dilanjutkan dengan melakukan revisi produk operasional. Dari masukan, kritik serta saran yang diperoleh dari uji coba utama digunakan sebagai bahan pertimbangan untuk revisi produk operasional sebelum produk digunakan untuk ujicoba operasional. Masukan dari siswa dan guru pada tahap uji coba pendahuluan lebih kearah pengembangan semua materi percobaan IPA yang terdapat pada kelas tinggi untuk dijadikan laboratorium virtual

8) Produk yang telah direvisi operasional kemudian digunakan untuk Uji coba operasional. Uji coba operasional lebih banyak melibatkan subjek penelitian dari pada ujicoba utama. Untuk uji coba operasional, dalam penelitian ini kami melibatkan 2 sekolah dengan kelas yang sama tetapi 1 sekolah negeri dan 1 sekolah swasta. Sekolah swasta yang digunakan adalah MI Maarif NU Rawalo 
dengan menggunakan 1 orang guru dan 1 kelas IV. Sedangkan sekolah Negeri yang digunakan adalah SDN 1 losari dengan menggunakan 1 orang guru dan 1 kelas IV sebagai subjek dari uji coba operasional.

9) Tahapan selanjutnya dari uji coba operasional adalah revisi produk akhir . Revisi produk akhir dilakukan jika terdapat masukan, kritik dan saran dari subjek uji coba operasional.

10) Akhir dari tahapan pengembangan produk adalah Deseminasi dan implementasi. Proses ini berupa penyebaran produk teknologi purwarupa laboratorium virtual berbasis pendidikan karakter yang didesiminasikan kepada 25 Sekolah Dasar di Kabupaten banyumas baik Negeri maupun swasta.

Data yang diperoleh dalam penilaian ini adalah data penilaian kualitas laboratorium virtual yang dilakukan oleh para ahli, guru serta siswa.Data tersebut diolah berdasarkan instrumen penilaian berupa lembar validasi diisi oleh ahli media, ahli materi,ahli psikologi, ahli bahasa, serta lembar angket yang diisi oleh guru kelas IV dan siswa kelas IV. Fokus dari Penilaian adalah untuk mengetahui kualitas laboratorium virtual berbasis pendidikan karakter menurut penilaian ahli media, ahli materi,ahli bahasa,ahli psikologi, ahli bahasa, guru kelas IV dan siswa kelas IV. Data yang diperoleh berupa data kualititatif yang diubah menjadi data kuantitaif. Ketentuan poin penilaian pada lembar validasi dibuat secara bertingkat. skor 5 untuk kategori sangat baik, skor 4 untuk kategori baik, skor 3 untuk kategori cukup baik,skor 2 untuk kategori kurang baik, dan skor 1 untuk kategori sangat kurang baik. Data tersebut kemudian diproses untuk menentukkan kualitas dari laboratorium virtual. Penialaian secara kualitatif kemudian diterjemahkan menjadi nilai kuantitaf. Hasil penilaian secara keseluruhan adalah baik. Rincian hasil penilaian oleh para ahli adalah :

Tabel 1. Data validasi Ahli Media Terhadap Kualitas laboratorium virtual

\begin{tabular}{llll}
\hline No. & Kriteria penilaian & Skor & Kategori \\
\hline 1 & Tampilan umum & 24 & Baik \\
2 & Tampilan khusus & 20 & Baik \\
3 & Penyajian laboratorium Virtual & 20 & Sangat baik \\
\hline
\end{tabular}

Tabel 2. Data validasi Ahli Materi Terhadap Kualitas Laboratorium Virtual

\begin{tabular}{llll}
\hline No. & Kriteria Penilaian & Skor & Kategori \\
\hline 1 & Relevansi & 30 & Sangat Baik \\
2 & Keakuratan & 28 & Baik \\
3 & Kelengkapan sajian & 9 & Baik \\
4 & Konsep dasar materi & 28 & Baik \\
5 & Kesesuaian materi dengan & 12 & Baik \\
\multicolumn{2}{l}{ pembelajaran yang berpusat pada siswa } & \\
\hline
\end{tabular}

Tabel 3. Data validasi Ahli Bahasa Terhadap Kualitas laboratorium virtual

\begin{tabular}{llll}
\hline No. & Kriteria Penilaian & Skor & Kategori \\
\hline 1 & Ketepatan kalimat & 12 & Baik \\
2 & Gaya bahasa & 13 & Baik \\
3 & Tata tulis & 12 & Baik \\
\hline
\end{tabular}


Tabel 4. Data Penilaian Ahli Psikologi Terhadap Kualitas laboratorium virtual

\begin{tabular}{llll}
\hline No. & Kriteria Penilaian & Skor & Kategori \\
\hline 1 & Religius & 24 & Baik \\
2 & Nasionalisme & 16 & Baik \\
3 & Mandiri & 12 & Baik \\
4 & Gotong royong & 20 & Baik \\
5 & Integritas & 12 & Baik \\
\hline
\end{tabular}

\section{SIMPULAN}

Berdasarkan pengembangan laboratorium virtual berrbasis pendidikan karakter didapatkan kesimpulan sebagai berikut:

1. Laboratorium Virtual berbasis pendidikan karakter telah dikembangkan sesuai dengan kurikulum 2013 kelas IV tema pahlawanku yang terdiri dari 3 subtema, subtema 1 perjuangan pahlawanku terdiri dari 5 percobaan, subtema 2 pahlawanku kebanggaan ku terdiri dari 2 percobaan. Subtema 3 sikap kepahlawan terdiri dari 1percobaan

2. Kualitas laboratorium Virtual berbasis pendidikan karakter Menurut para ahli media, ahli bahasa, ahli psikologi, ahli materi serta penilaian guru serta siswa termasuk dalam kategori baik.

\section{DAFTAR PUSTAKA}

Andrianto, Tuhana Tufiq. (2011). Mengembangkan Karakter Sukses Anak di EraCyber. Yogyakarta: Ar-Ruzz Media.

Borg, W.R. dan Gall, M.D. (1989). Educational Research: An Introduction, Fifthy Edition. New York: Longman

Dwiyanti N Aris. (2017). Pengunaan Media Pembelajaran Berbasis Kearifan Lokal untuk Meningkatkan Minat dan Hasil Belajar Siswa. Jurnal Pancar.1,1(2017):4050

Hamdu, Ghullam,Lisa Agustina. (2011) Pengaruh Motivasi Belajar Siswa Terhadap Pestasi Belajar Ipa Di Sekolah Dasar. Jurnal penelitian pendidikan. 12.1(2011):81-86

Jaya, Hendra. (2012). Pengembangan Laboratorium Virtual Untuk Kegiatan Praktikum Dan Memfasilitasi Pendidikan Karakter Di Smk. Jurnal Pendidikan Vokasi, 2.1, (2012): 80-90

Kementrian Pendidikan dan Kebudayaan. (2013). Draf Dokumen Kurikulum. Jakarta: Kemendikbud

Megawangi, Ratna. (2004). Pendidikan Karakter Solusi Yang Tepat Untuk Membangun Bangsa. Jakarta: Indonesia Heritage Foundation

Riwanto A Mawan, Rahayuni Galuh. (2018). Pengembangan Media Pembelajaran IPA Interaktif Berbasis Keterampilan Proses Sains untuk Kelas Atas Sekolah Dasar. Jurnal Pancar.2,2(2018):20-30

Samatowa, Usman. (2011). Pembelajaran IPA di Sekolah Dasar. Jakarta: Indeks

Sriwilujeng,Dyah. (2017). Panduan Implementasi Penguatan Pendidikan Karakter.Jakarta: Esensi Erlangga Grup. 